\title{
Comparion of Growth Hormone Responses to Human Pancreatic Growth Hormone Releasing Factor and Other Pharma- cological Stimuli in Acromegalic Patients
}

\author{
Tsuyoshi KARASHIMA, Kensaku SEKIYA, Shoichiro IKUYAMA, \\ KEN-ICHI KATO AND HiROSHI IBAYASHI
}

Third Department of Internal Medicine, Faculty of Medicine, Kyushu University, Fukuoka 812

\begin{abstract}
Synthetic human pancreatic growth hormone releasing factor (pGRF) was administrated intravenously to 14 acromegalic patients, and the response of plasma GH to pGRF was compared with that to TRH, GnRH or other GHstimulating agents in these patients. Three patients hyperresponded (more than 8 times), 4 patients responded (2-4 times), 4 patients hyporesponded (1.5-2.0 times) and 3 patients did not respond at all. There was no correlation between the responses to TRH and pGRF, however, an intimate relationship was observed between responses to pGRF and GnRH in the patients who hyperresponded to pGRF. A patient not responding to pGRF showed a marked response to insulin or clonidine and another patient not responding to insulin or clonidine did respond to pGRF. Similarly, some patients not responding to FK 33-824, a met-enkephalin analog, or arginine did respond to pGRF.
\end{abstract}

A 44 amino acid residue pancreatic growth hormone-releasing factor (pGRF) was isolated and characterized from a pancreatic tumor of a patient with acromegaly (Guillemin et al., 1982). Restoration analysis of genomic DNA indicates that pGRF in the pancreas and the hypothalamus is the same substance (Mayo et al., 1983). This pGRF selectively stimulates growth hormone $(\mathrm{GH})$ secretion in man (Gelato et al., 1983: Rosenthal et al., 1983).

It has been proposed that the lack of increase in $\mathrm{GH}$ in acromegalic patients, determined by the insulin stimulation test or arginine infusion test is due to autonomicity of GH-producing adenoma (Daughaday and Cryer, 1980). If so, these

Received March 15, 1984 patients will not respond to pGRF. On the other hand, a close relation was reported between somatostatin and TRH, GnRH or arginine (Hanew et al., 1980) and between somatostatin and GnRH (Pieters et al., 1982). Recently, Shibasaki et al., (1984a) reported that pGRF raised the plasma $\mathrm{GH}$ level to various degrees in acromegalic patients. We compared the GH responses between GRF and other substance, i.e. TRH, GnRH, insulin, arginine, clonidine or FK 33-824, in acromegalic patients. The objective of this study was to determine [1] if the response to pGRF is related to responses to other hypothalamic releasing hormones, TRH and GnRH, and [2] if the response to pGRF was related to other centrally mediated stimuli, such as insulin-induced hypoglycemia, arginine, clonidine or FK 33-824. 


\section{Subjects and Methods}

Fourteen Japanese acromegalic patients ( 7 men and 7 women: ages 29-72) were chosen for this study. Informed consent was obtained from each patient. The existence of a pituitary tumor was confirmed by transsphenoidal surgery in 12 patients. Eight patients still having remnants of the tumor after the surgery were not given any postoperative pituitary hormone replacement therapy. In 4 of the 12 patients, GRF and other pharmacological tests were performed before surgery, while the remaining 8 patients with a remnant tumor were studied after the operation. The other 2 patients, who had not yet undergone surgery, had enlargement and/or destruction of the sella turcica, as seen by Xray examination and $\mathrm{CT}$ scanning and this suggested the presence of a pituitary adenoma. These patients also had elevated basal levels of plasma GH which were not suppressed by $75 \mathrm{~g}$ oGTT. In some patients treated with bromocriptine, this drug was withdrawn at least one week prior to the GRF test.

After an overnight fast, an indwelling cannula for blood withdrawal and administration of pGRF was inserted into a forearm vein of the patients who had been kept supine in bed for $120 \mathrm{~min}$. pGRF was purchased from Peninsula Co. (California). One hundred $\mu \mathrm{g}$ of the peptide, dissolved in $1.0 \mathrm{ml}$ normal saline containing $1 \mathrm{mM} \mathrm{HCl}$ and $1 \mathrm{mM}$ ascorbic acid and sterilized by filtration through a $0.22 \mu \mathrm{m}$ filter, was administered as a bolus, according to the method of Shibasaki et al. (1984a).

$2 \mathrm{ml}$ blood samples were drawn $-15,0,15$, $30,45,60,90$ and $120 \mathrm{~min}$. after injection of pGRF. TRH (Tanabe Pharm. Co., $500 \mu \mathrm{g}$ ) and GnRH (Tanabe Pharm. Co., $100 \mu \mathrm{g}$ ) intravenously as a bolus, arginine $(30 \mathrm{~g})$ intravenously as drip inf usion for $30 \mathrm{~min}$., clonidine $\left(0.15 \mathrm{mg} / \mathrm{m}^{2}\right)$ orally and FK 33-824 (Sandoz, $0.5 \mathrm{mg}$ ) intramuscularly were administrated and blood samples were drawn every $30 \mathrm{~min}$. during $120 \mathrm{~min}$. for FK 33-824 and insulin, every $30 \mathrm{~min}$. during $180 \mathrm{~min}$. for clonidine and $0,15,30,60,90,120 \mathrm{~min}$. for $\mathrm{TRH}$ and GnRH. After 3 to 30 day interval, each test was performed in the same subjects.

Plasma GH levels were determined by a specific radioimmunoassay for human GH (Eiken Immunochemical Laboratory, Tokyo). The intraand inter-assay coefficients of variation were 6.6

$\%$ and $6.0 \%$, respectively.

\section{Results}

The basal levels of plasma $\mathrm{GH}$ in 14 acromegalic patients ranged from 5.7 to 171 $\mathrm{ng} / \mathrm{ml}$. The responses varied with regard to plasma $\mathrm{GH}$ following administration of pGRF (Fig. 1). When peak levels were compared with basal ones, 3 patients responded to pGRF more than 7 times, 3 patients 2-3 times, 4 patients fewer than twice and more than 1.5 times and 3 patients did not respond. The GH peak of the responders was observed at 15 to $90 \mathrm{~min}$. after the administration of pGRF.

In 13 of these patients, TRH and GnRH test were performed. Fig. 2a shows the relation between the ratio of peak to basal $\mathrm{GH}$ values in the GRF test and that observed in the TRH test. When the criterion of a positive response is defined as an increase of more than twice, the number of responders to both pGRF and TRH was 5, that of nonresponders to both was 2 , that of patients who responded to pGRF, but not to TRH was 3 and that of those who responded to TRH but not to pGRF was 5 .

Fig. $2 b$ shows the relation between the ratio of peak to basal $\mathrm{GH}$ values on GRF test and that observed on the GnRH test. The number of nonresponders to both was 6 , that of responders to both was 4 , that of patients who responded to pGRF but not to GnRH was 3 and that of patients who responded to GnRH but not to pGRF was 1. Three patients who responded to pGRF more than 8 times also responded to GnRH.

Table 1 shows the relation between GRF test and other stimulation tests, i.e. insulin stimulation test (IST), arginine infusion test, clonidine test and FK 33-824 test. The number of responders to both pGRF and IST was 1 , that of nonresponders to both was 2, that of patients who responded to pGRF 


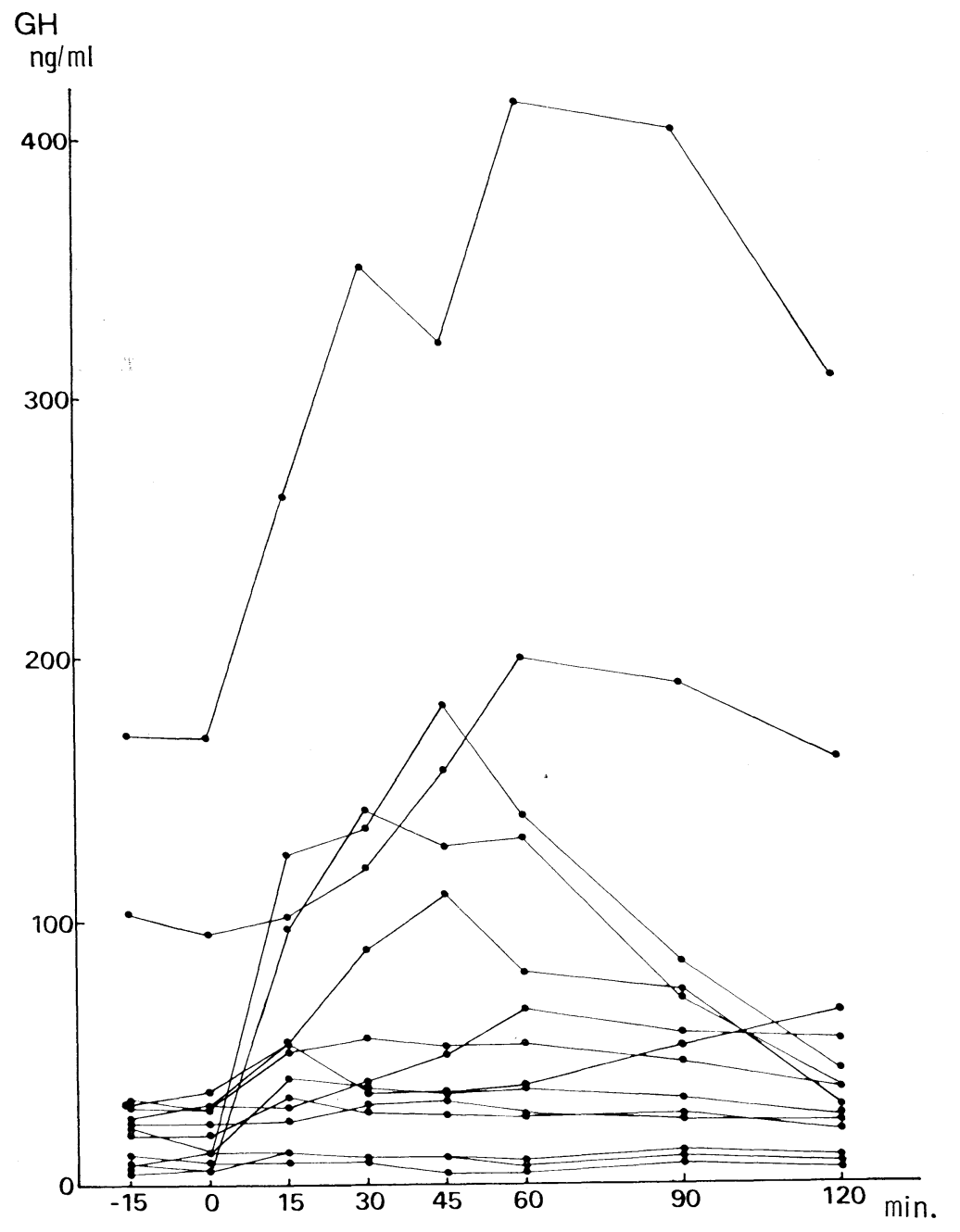

Fig. 1. Effects of administration of GRF on plasma $\mathrm{GH}$ in 14 acromegalic patients.

but not to IST was 2 and that of those who responded to IST but not to pGRF was 2 (Table 1a). In the clonidine test, the number of patients who responded to pGRF but not to clonidine was 1 and those who responded to clonidine but not to pGRF numbered 2 (Table $1 \mathrm{~b}$ ). The number of patients who responded to pGRF but not to arginine was 2 and that of nonresponders was 1 (Table 1c). The number of patients who responded to pGRF but not to FK 33-824 was 4 and that of nonresponders to both was 1 (Table 1d).

\section{Discussion}

Shibasaki et al. (1984a) reported that acromegalic patients can be classified into 3 groups i. e. hyperresponse, low response and no response to pGRF. Our present data support their findings. Nine of our patients with acromegaly were over 40 years of age. Age-related GH response to pGRF in man has been reported and some subjects over 40 showed no increase in plasma GH after pGRF administration (Shibasaki 
a.

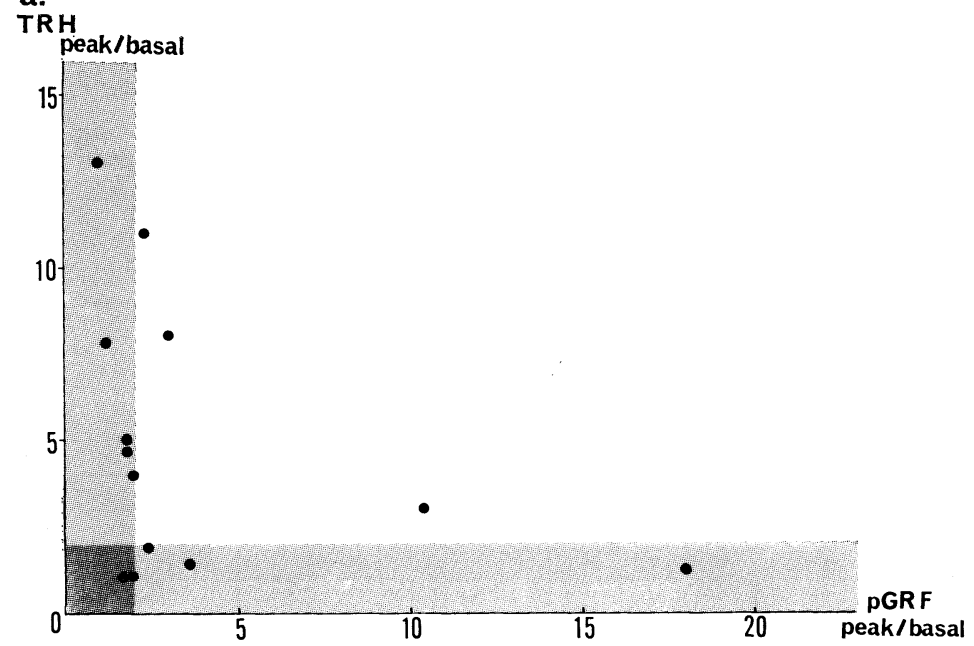

b.

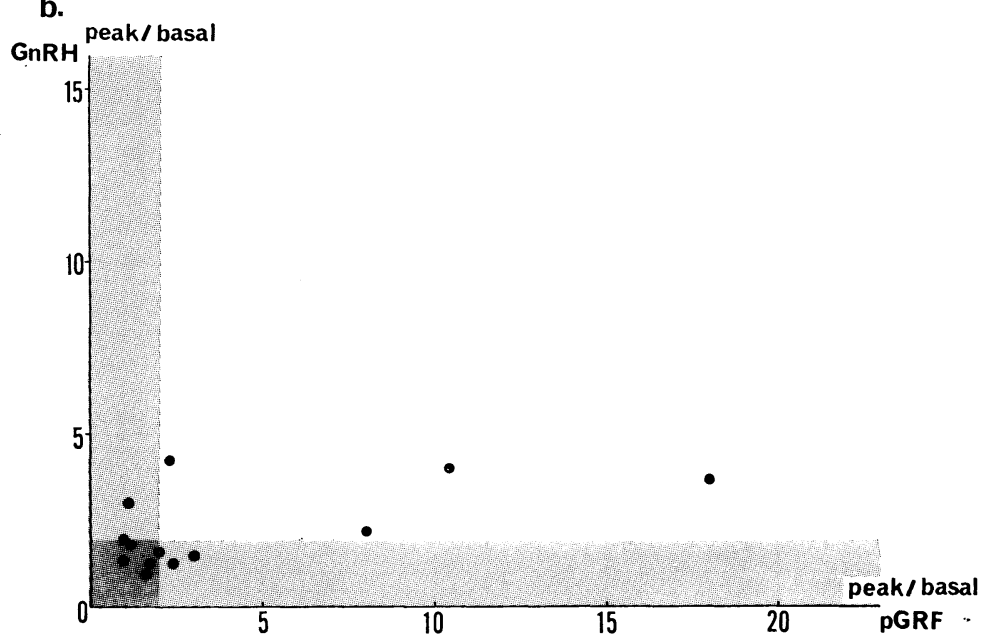

Fig 2. a ; The relationship between ratio of peak to basal GH on GRF test and that observed with the TRH test.

b; The relationship between ratio of peak to basal GH on GRF test and that observed with GnRH test. et al., 1984b). Thus in 3 patients with no response to pGRF who were over 57, the factor involved may not be autonomicity of the $\mathrm{GH}$-producing adenoma but rather agerelated.

There was no correlation between the GRF and TRH tests though it is of interest that 3 patients who did not respond to pGRF responded to TRH 4-12 times. On the other hand, 4 of 5 patients who responded to GnRH, and all 3 patients who hyperresponded to GnRH more than 8 times, responded to pGRF. A close relationship. between the action of somatostatin and that of GnRH has been reported (Pieters et al., 1982). Many acromegalic patients did not exhibit normal GH secretory responses to pharmacologic stimuli such as administration of insulin or infusion of arginine and this lack of response is thought to be due to autonomicity of $\mathrm{GH}$ producing-adenoma (Daughaday and Cryer, 1980). We also observed that the administration of clonidine, which may release pGRF via $\alpha_{2}$-adrenergic receptor at the hypothalamus (Martin, 1983), did or did not stimulate the $\mathrm{GH}$ release in 
a.

Table 1

\begin{tabular}{|c|c|c|c|c|c|c|}
\hline \multirow[b]{2}{*}{ Case No. } & \multirow[b]{2}{*}{ Sex } & \multirow[b]{2}{*}{ Age } & \multirow{2}{*}{$\frac{\text { GH response to GRF }}{\text { peak/basal }}$} & \multicolumn{3}{|c|}{ GH response to IST } \\
\hline & & & & $\begin{array}{l}\text { basal value } \\
(\mathrm{ng} / \mathrm{ml})\end{array}$ & $\begin{array}{l}\text { peak value } \\
(\mathrm{ng} / \mathrm{ml})\end{array}$ & peak/basal \\
\hline $1^{*}$ & $\mathrm{~F}$ & 42 & 9.74 & 10.0 & 26.1 & 2.58 \\
\hline $2 *$ & M & 43 & 18.5 & 7.8 & 11.3 & 1.44 \\
\hline 3 & M & 29 & 2.41 & 32.5 & 34.3 & 1.06 \\
\hline 4 & $\mathrm{~F}$ & 31 & 1.84 & 48.0 & 165 & 3.44 \\
\hline $5^{*}$ & $\mathbf{M}$ & 38 & 1.71 & 22.0 & 46.2 & 2.10 \\
\hline $6 *$ & $\mathbf{M}$ & 62 & 1.17 & 10.0 & 11.1 & 1.11 \\
\hline 7 & $\mathrm{~F}$ & 59 & 1.12 & 6.0 & 13.7 & 2.28 \\
\hline 8 & $\mathrm{~F}$ & 54 & 1.97 & 65.6 & 71.3 & 1.09 \\
\hline
\end{tabular}

b.

\begin{tabular}{|c|c|c|c|c|c|c|}
\hline \multirow[b]{2}{*}{ Case No. } & \multirow[b]{2}{*}{ Sex } & \multirow[b]{2}{*}{ Age } & \multirow{2}{*}{$\begin{array}{c}\text { GH response to GRF } \\
\text { peak/basal }\end{array}$} & \multicolumn{3}{|c|}{$\mathrm{GH}$ response to clonidine } \\
\hline & & & & $\begin{array}{l}\text { basal value } \\
(\mathrm{ng} / \mathrm{ml})\end{array}$ & $\begin{array}{l}\text { peak value } \\
(\mathrm{ng} / \mathrm{ml})\end{array}$ & peak/basal \\
\hline $2^{*}$ & M & 43 & 18.5 & 8.2 & 26.4 & 3.21 \\
\hline $5^{*}$ & M & 38 & 1.71 & 12.0 & 13.3 & 1.11 \\
\hline 7 & $\mathrm{~F}$ & 59 & 1.12 & 11.0 & 32.8 & 2.98 \\
\hline $9 *$ & $\mathrm{~F}$ & 49 & 8.0 & 11.5 & 14.0 & 1.27 \\
\hline
\end{tabular}

c.

\begin{tabular}{|c|c|c|c|c|c|c|}
\hline \multirow[b]{2}{*}{ Case No. } & \multirow[b]{2}{*}{ Sex } & \multirow[b]{2}{*}{ Age } & \multirow{2}{*}{$\frac{\text { GH response to GRF }}{\text { peak } / \text { basal }}$} & \multicolumn{3}{|c|}{ GH response to arginine } \\
\hline & & & & $\begin{array}{l}\text { basal value } \\
(\mathrm{ng} / \mathrm{ml})\end{array}$ & $\begin{array}{l}\text { peak value } \\
(\mathrm{ng} / \mathrm{ml})\end{array}$ & peak/basal \\
\hline 4 & $F$ & 31 & 1.84 & 28.0 & 43.0 & 1.54 \\
\hline 8 & 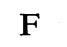 & 54 & 1.97 & 53.9 & 54.9 & 1.02 \\
\hline $9 *$ & $\mathrm{~F}$ & 49 & 7.80 & 13.6 & 13.0 & 0.96 \\
\hline $10^{*}$ & $\mathrm{~F}$ & 43 & 3.76 & 12.0 & 35.8 & 2.98 \\
\hline
\end{tabular}

d.

\begin{tabular}{|c|c|c|c|c|c|c|}
\hline \multirow[b]{2}{*}{ Case No. } & \multirow[b]{2}{*}{ Sex } & \multirow[b]{2}{*}{ Age } & \multirow{2}{*}{$\frac{\text { GH response to GRF }}{\text { peak/basal }}$} & \multicolumn{3}{|c|}{ GH response to FK $33-824$} \\
\hline & & & & $\begin{array}{l}\text { basal value } \\
(\mathrm{ng} / \mathrm{ml})\end{array}$ & $\begin{array}{l}\text { peak value } \\
(\mathrm{ng} / \mathrm{ml})\end{array}$ & peak/basal \\
\hline 4 & $\mathrm{M}$ & 27 & 2.41 & 27.3 & 66.3 & 2.43 \\
\hline $6^{*}$ & M & 62 & 1.17 & 8.8 & 10.2 & 1.16 \\
\hline $10^{*}$ & $\mathrm{~F}$ & 43 & 3.76 & 16.0 & 13.0 & 0.81 \\
\hline $11^{*}$ & $\mathbf{M}$ & 36 & 1.20 & 99.4 & 201 & 2.02 \\
\hline 12 & $\mathrm{~F}$ & 33 & 2.42 & 211 & 85 & 0.40 \\
\hline
\end{tabular}

*; the patient who had transsphenoidal surgery.

patients with acromegaly (unpublished observation). In the present study, patients 3 , 8 and 9 responded to pGRF but not to insulin or clonidine. Proof of the existence in acromegalic patients of a defective catecholaminergic function in the central nervous system has been presented (Camanni et al., 1982). Therefore, in these 3 patients, it is more likely that there is dysfunction of GRF releasing mechanisms, probably catecholaminergic function at the level of hypothalamus, rather than that there is an autonom- 
icity of the GH-producing adenoma, because pGRF did release $\mathrm{GH}$ in these patients. Patient 7 who did not respond to pGRF responded to insulin-induced hypoglycemia and clonidine. In this case, it is possible that a substance other than GRF stimulates the $\mathrm{GH}$ release or that insulin or clonidine inhibits the release of hypothalamic somatostatin, thereby stimulating $\mathrm{GH}$ release.

FK 33-824 acts via a central opioid receptor and stimulates GH release via GRF (Katakami et al., 1981) and there is no increase in plasma GH after the administration of FK 33-824 in patients with acromegaly (Demura et al., 1981: Delitala et al., 1981). The lack of response indicated a central dysfunction of a opioid mechanism rather than autonomicity of the GH-producing adenoma, because response to pGRF is preserved in most patients with acromegaly. Similarly, the lack of response to arginine may be due to a central dysfunction, as this agent seems to act on central neurons (Martin, 1983).

\section{References}

Camanni, F., F. Massara, M. Santia, G. M. Molinatti and E. E. Müller (1982). Impaired prolactin responsiveness to dopamine antagonist in acromegaly. Metabolism 31, 1090-1095.

Daughaday, W. H. and P. E. Cryer(1980). Growth hormone hypersecretion and acromegaly. In Neuroendocrionology, edited by Krieger D.T. and Hughes J. C., Sinauer Associates Inc., Sunderland.

Demura, R., T. Suda, I. Wakabayashi, M. Yoshimura, K. Jibiki, E. Odagiri, H. Demura and K. Shizume (1981). Plasma pituitary hormone responses to the synthetic enkephalin analog (FK 33-824) in normal subjects and patients with pituitary diseases. J. Clin. Endocrinol. Metab. 52, 263-266.

Gelato M. C., O. Pescovitz, F. Cassorla, D. L. Loriaux and G. R. Merriam (1983). Effects of a growth hormone releasing factor in man. J. Clin. Endocrinol. Metab. 57, 674-676.

Guillemin, R., P. Brazeau, F. Esch, N. C. Ling and W. B. Wehrenberg (1982). Growth hormone-releasing factor from a human pancreatic tumor that caused acromegaly. Science 218, 585-587.

Hanew, K., M. Kokubun, A. Sasaki, T. Mouri and K. Yoshinaga (1980). The spectrum of pituitary growth hormone responses to pharmacological stimuli in acromegaly. J. Clin. Endocrinol. Metab. 51, 292-297.

Katakami, H., Y. Kato, N. Matsushita, S. Hiroto, A. Shimatsu and H. Imura (1981). Involvement of alpha-adrenergic mechanisms in growth hormone release induced by opioid peptides in conscious rats. Neuroendocrinology 33, 129135.

Martin, J. B. (1983). Neuroendocrine regulation of growth hormone secretion. Pediat. Adolesc. Endocrinol. 12, 1-26.

Mayo, K. E., W. Vale, J. Rivier, M. G. Rosenfeld and R. M. Evans (1983). Expressioncloning and sequence of a cDNA encloding human growth hormone-releasing factor. Nature $306,86-88$.

Pieters, G. F. F. M., J. E. Romeijn, A. G. H. Smals and P.M.C. Kloppenborg (1982). Somatostatin sensitivity and growth hormone responses to releasing hormones and bromocryptin in acromegaly. J. Clin. Endocrinol. Metab. 54, 942-947.

Rosenthal, S. M., E. A. Schriock, S. L. Kaplan, R. Guillemin and M. Gruvbach (1983). Synthetic human pancreas growth hormone-releasing factor (hpGRF 1-44- $\mathrm{NH}_{2}$ ) stimulates growth hormone secretion in normal man. J. Clin. Endocrinol. Metab. 57, 677-679.

Shibasaki, T., K. Shizume, A. Masuda, M. Nakahara, N. Hizuka, M. Miyakawa, K. Takano, H. Demura, I. Wakabayashi and N. Ling (1984a). Plasma growth hormone response to growth hormone-releasing factor in acromegalic patients. J. Clin. Endocrinol. Metab. 58, 212-214.

Shibasaki, T., K. Shizume, M. Nakahara, A. Masuda, K. Jibiki, H. Demura, I. Wakabayashi and N. Ling (1984b). Age-related changes in plasma growth hormone-releasing factor in man. J. Clin. Endocrinol. Metab. 58, 215-217. 